\title{
Prematüre Bebek Annelerinin Yenidoğan Yoğun Bakım Deneyimleri $\infty$
}

\author{
Dilek ERYÜRÜK ${ }^{1}$, Öznur BAŞDAŞ ${ }^{2}$, Zübeyde KORKMAZ ${ }^{3}$, ilknur YILDIZ ${ }^{4}$, \\ Özlem MUMCU ${ }^{5}$, Meral BAYAT ${ }^{6}$
}

\section{öz}

Amaç: Sağlıklı bir bebeğe kavuşmayı bekleyen anne, erken doğumu takiben Yenidoğan Yoğun Bakım Ünitelerindeki (YYBÜ) koşullar nedeniyle kriz yaşayabilir. Bu krizin başarılı bir şekilde yönetilebilmesi için annelerin yaşadıkları duyguların ve beklentilerinin belirlenmesi önemlidir. Bu çalışma, YYBÜ’ye yatan bebeklerin annelerinin beklenti ve deneyimlerinin belirlenmesi amacı ile nitel çalışma olarak yapılımıştır.

Gereç ve Yöntem: Çalışmanın verileri, YYBÜ’ye bebeği yatan 10 anne ile derinlemesine bireysel görüşme yapılarak toplanmıştır. Elde edilen veriler içerik analizi ile değerlendirilmiştir. Annelerin; yaşadıkları duygular, bebeğin bakımına ilişkin görüşleri ve hemşirelerden beklentileri derlenerek sunulmuştur.

Bulgular: Çalışmada annelerin bebekleri ile ilgili anksiyete, kaygı, korku ve üzüntü yaşadıkları, bebeğin durumu ile ilgili açık-anlaşıı bilgi almak ve bebeklerinin bakımına katılmak istedikleri belirlenmiştir.

Sonuç: YYBÜ’ye bebeği yatan annelerin yaşadıkları duygular ve kriz durumu ile baş edebilmeleri için hemşirelerin annelere YYBÜ'yü tanıtmaları, bebeklerine ilişkin açık-anlaşıır bilgi vermeleri, anne bebek etkileşimini ve annenin bakıma katılmasını desteklemeleri önerilmektedir.

Anahtar kelimeler: Anne deneyimi, bebek, hemşire, yenidoğan yoğun bakım ünitesi

\begin{abstract}
Neonatal Intensive Care Experiences of Mothers of Premature Babies

Aim: While a mother expects a healthy baby, she may experience a crisis due to the conditions in the neonatal intensive care units (NICU) following premature birth. It is important to determine the feelings and expectations of mothers to manage this crisis successfully. This study was conducted as a qualitative study to determine the expectations and experiences of the mothers of babies hospitalized in the NICU.

Material and Methods: The data were collected through in-depth individual interviews with ten mothers whose babies were hospitalized in the NICU. The obtained data were evaluated by content analysis. Emotions experienced by the mothers, their views on the care of the baby, and their expectations from the nurses were compiled and presented.

Results: It was determined that mothers felt anxiety, fear, and sadness about their babies; they wanted to get clear and understandable information about the baby's condition and participate in their babies' care.

Conclusion: Nurses are recommended to introduce NICU tomothers, provide clear and understandable information about their babies, support mother-infant interaction and mother's participation in care to cope with the emotions and crisis experienced by mothers whose babies are hospitalized in NICU. Keywords: Baby, maternal experience, neonatal intensive care unit, nurse
\end{abstract}

${ }^{1}$ Dr. Erciyes Üniversitesi, Sağlık Bilimleri Enstitüsü, Çocuk Sağlığı ve Hastalıkları Hemşireliği Doktora Programı Mezunu, Türkiye, E-posta: deryuruk@ hotmail.com, Tel: 05522417130, ORCID: 0000-0002-4972-8276

${ }^{2}$ Doç.Dr., Erciyes Üniversitesi Sağlık Bilimleri Fakültesi, Çocuk Sağlığı ve Hastalıkları Hemşireliği Anabilim Dalı, Kayseri, Türkiye, E-posta:obasdas@erciyes.edu.tr, Tel:03524374937/28568, ORCID: 0000-0003-0752-6614

${ }^{3}$ Dr.Öğr. Üyesi, Nuh Naci Yazgan Üniversitesi, Sağılı Bilimleri Fakültesi, Çocuk Sağlığı ve Hastalıkları Hemşireliği Anabilim Dalı, Kayseri, Türkiye, Eposta:32korkmaz@gmail.com, Tel: 05327113562, ORCID: 0000-0002-5516-4032

${ }^{4}$ Dr.Öğr. Üyesi, Sivas Cumhuriyet Üniversitesi, Sağlık Bilimleri Fakültesi, Çocuk Sağlığı ve Hastalıkları Hemşireliği Anabilim Dalı, Sivas, Türkiye, E-posta: ilknuryildiz@yahoo.com.tr,Tel: 05373769715, ORCID: 0000000225747018

5Uzman Hemşire, Eskişehir Şehir Hastanesi, Eskişehir, Türkiye, E-posta: ozlemmmumcu2015@gmail.com, Tel: $05549204542,0 R C I D: 0000000201047834$

${ }^{6}$ Prof.Dr., Erciyes Üniversitesi Sağlık Bilimleri Fakültesi, Çocuk Sağlığı ve Hastalıkları Hemşireliği Anabilim Dalı, Kayseri, Türkiye, E-posta: mbayat@erciyes.edu.tr, Tel: 03524374937/28552, ORCID:0000-0002-7076-1097

Geliş Tarihi: 03 Eylül 2020, Kabul Tarihi: 30 Mart 2021

Atıf/Citation:Eryürük D, Başdaş Ö, KorkmazZ, Yıldızi, Mumcu Ö, Bayat M.Prematüre Bebek Annelerinin Yenidoğan Yoğun Bakım Deneyimleri. Hacettepe Üniversitesi Hemşirelik Fakültesi Dergisi 2021; 8(2):196-202. DOI: 10.31125/hunhemsire.968835 


\section{GíRiş}

Doğum yapmak ve bebek sahibi olmak insan hayatında önemli bir olaydır ${ }^{1-3}$. Ebeveynler sağlıklı ve normal gelişimini tamamlamış bir bebeğe sahip olmayı hayal ederler. Zamanından önce, henüz gelişimini tamamlamamış bir bebeğin doğumu ve YYBÜ'ye yatışı ile ebeveynler stres ve kriz yaşarlar ${ }^{1,3,4-8}$. Bu durumda inkâr, öfke, suçluluk, depresyon ve benlik saygısının azalması gibi tepkiler gösterebilirler ${ }^{1,7,9}$.

Yenidoğan döneminde hastaneye yatışın en önemli nedenlerinden biri olan prematüreliğin ebeveynlerde stres düzeyini arttırdığı, hastalığın derecesine bakılmaksızın, çok kısa süreli yatışların bile bebek ve aile için travmatik olduğu bilinmektedir6,8,10-12. Yine YYBÜ'depreterm bebeği olan ebeveynler ile yapılan çalışmalarda, ebeveynlerin depresyon, anksiyete, kontrol kaybı, gelecek korkusu, rol değişimi ve bebeğin iyileşmesine yönelik endişeler yaşadığı görülmüştür $5,7,13$.

Yüksek teknoloji donanımları ile dikkat çeken YYBÜ'lerin, kalabalık, ışıklı, gürültülü ve ürkütücü yapısı ailelerin yaşadığı stresi artırmaktadır ${ }^{14}$. Bebeği ile etkileşimi bozulan ve bakımdan uzak tutulan aileler kendilerini çaresiz, gergin, sinirli ve karmaşık hissederler ${ }^{15}$. Çok küçük ve savunmasız olan bebeğini bilmediği cihazlara bağlı olarak gören ebeveynler keder ve üzüntü yaşayarak, yoğun bakım sürecine ilişkin olumlu veya olumsuz düşünce ve/veya deneyimler yaşarlar ${ }^{6,8,16-17}$.

Ebeveynlerin YYBÜ'ye ilişkin olumlu deneyimler edinmelerinde sağlık ekibi üyelerinin rolü oldukça önemlidir. Bu noktada YYBÜ'nde bebeği olan ebeveynlerin duygu ve deneyimlerini ifade etme gereksinimlerinin desteklenmesi önemlidir ${ }^{7,9}$. Lohusalığında etkisiyle daha duygusal tepkiler veren annelerin bu kritik süreçle baş etmelerinde sağlık ekibi üyelerinin desteği önem kazanır. Özellikle yenidoğana bütüncül bakım veren hemşirelerin bu konudaki girişimleri anneler için vazgeçilmezdir. Hemşireler YYBÜ'nde, yenidoğan ve ebeveynlerin psikolojik, psikososyal ve sosyokültürel ihtiyaçlarına odaklanmalı, ebeveynleri bakıma katmalı ve özellikle anneler ile iş birliği içinde olmalıdır ${ }^{1,7,9,17-}$ 18. Ayrıca hemşireler YYBÜ'lerinde etkili bakım verebilmek için; yenidoğanı bütüncül değerlendirmeleri ve annelerinin duygularını, bebeğin bakımına ilişkin görüşlerini ve hemşirelerden beklentilerini içeren bir bakım planı oluşturmalıdır ${ }^{16,19}$.

\section{Araştırmanın Amacı}

$\mathrm{Bu}$ çalışma, prematüre bebeği YYBÜ'ye yatan annelerin beklenti ve deneyimlerinin belirlenmesi amacı ile yapılmıştır.

\section{GEREÇ ve YÖNTEM}

\section{Araştırmanın Türü}

$\mathrm{Bu}$ çalışma, prematüre bebeği YYBÜ’ye yatan annelerin beklenti ve deneyimlerinin belirlenmesi amacı ile derinlemesine görüşme tekniği ile nitel araştırma türünde yapılmıştır.

\section{Araştırma Evren ve Örneklemi}

Araştırmanın örneklemini, çalışmanın yapıldığı devlet hastanesinin YYBÜ'ye 01-31 Ocak 2015 tarihleri arasında prematüre bebeği yatan, 18 yaş üzeri, herhangi bir iletişim engeli olmayan 21 anne oluşturmuştur. Nitel araştırmalarda, araştırma kapsamına alınacak kişi sayısına ilişkin kesin bir kural belirtilmemektedir. Derinlemesine yapılan görüşmelerde veri doyumuna ulaşılması amaçlanmaktadır ${ }^{20-22}$. Çalışmada veri doygunluğuna ulaşılması nedeniyle araştırmayı katılmayı kabul eden 10 anne ile veri toplama aşaması sonlandırılmıştır.

\section{Veri Toplama Araçları}

Veriler, araştırmacılar tarafından literatür taranarak oluşturulan 'Anne Görüşme Formu' ile toplanmıştır. Formda anne ve bebeğin sosyo-demografik özelliklerine ilişkin sorular ve prematüre bebek sahibi olma, bebeğin bakımı, ünitede yapılan uygulamalar ve hemşirelerden beklentilerine yönelik yarı yapılandııılmış sorular bulunmaktadır.

\section{Verilerin Toplama Araçlarının Uygulanması}

Derinlemesine bireysel görüşmeler gürültü ve bölünmelerin olmadığı ortamda bir araştırmacı tarafından yapılmış ve görüşmeler ses kayıt cihazına kaydedilmiştir. Her anne ile bir kez derinlemesine görüşme yapılmış, görüşme süreleri veri tekrarı ve veri doygunluğu esas alınarak ortalama 30-35 dakika sürmüştür. Görüşmelerin deşifresi başka bir araştırmacı tarafından yapılmıştır.

\section{Verilerin Analizi}

Deşifresi yapılan derinlemesine görüşmelerin içerik analizi Çocuk Sağlığı ve Hastalıkları Hemşireliği alanında uzman üç kişi tarafından tartışılarak yapılmıştır. Yapılan içerik analizi neticesinde üç tema ve alt temaları oluşturulmuştur.

\section{Araştırmanın Etik Boyutu}

Çalışmaya başlamadan önce bir üniversitenin girişimsel olmayan klinik araştırmalar etik kurulundan etik kurul onayı (23.01.2015/1426) alınmıştır. Annelere çalışma ile ilgili bilgi verilmiş, yazılı ve sözlü onamları alınmıştır.

\section{Araştırmanın Sınırlılıkları}

Bu araştırma, bir devlet hastanesinin YYBÜ'de bebeği yatan belirli sayıda gönüllü anne görüşleriyle sınırlıdır ve araştırmadan elde edilen bulgular bu araştırma grubuna genellenebilir.

\section{BULGULAR}

Çalışmaya katılan annelerin yaş ortalaması 28,2 (24-40 yaş aralığında) ve \%60'ı ilkokul mezunudur. Katılımcıların $\% 50$ 'sinin ilk annelik deneyimi olduğu saptanmıştır.

Çalışmadan elde edilen veriler içerik analizi sonrasında annelerin yaşadıkları duygular, bebeğin bakımına ilişkin görüşleri ve hemşirelerden beklentileri olmak üzere üç tema oluşturulmuştur.

\section{Annenin Yaşadığı Duygular}

Çalışmaya katılan annelere prematüre bebeğe sahip olma ve bebeğinin YYBÜ'ye yatıyor olma durumunun nasıl bir deneyim olduğu sorulduğunda bütün anneler "çok kötü ve üzüntü verici bir durum" olarak tanımlamışlardır. Annelerin; yarısının (beş anne) ilk annelik deneyimi olduğu, ne yapacaklarını bilemedikleri, bebeğin sağlığına ilişkin büyük kaygı duydukları, anksiyete yaşadıkları, korku ve üzüntü hissettikleri saptanmıştır.

1. anne: "ne bileyim bi dondum kaldım yani."

2. anne: "çok kötü etkilendim. Merak ediyorsunuz bir sorun çıkar mı? Yaşar mı? Yaşamazmı? Kâbus gibi. Yoğun bakım 
zaten yoğun dedin mi bittik yani çok kötü hissediyorsun. Evde hiçbir şeyini açtırmak istemedim. Çok kötüydü yani..." 3. anne: "Çok üzüldüm çok üzücü bir durum. Çok üzüсü...çoküzücü. Ama bir yanda da diyorum hani onlar sağlıklı olsun da burada da olsun diyorum yani. Yeterki iyi olsun da burada olacaksa burada olsun. ilk gördüğümde ay çok duyguluydu çok... Çok ağladım... Çok ağladım kuvözün başında çok ağladım... Insan dayanamıyor."

Anneler ilk kez YYBÜ'ye girdiğinde ve bebeği ziyaret ettiğinde, bebeğin gelişimi, emmesi ile ilgili geleceğe dönük yoğun kaygılar yaşadıklarını belirtmişlerdir.

5. anne: "Ciğerleri falan gelişmeyeceği için biraz korkuttu, biraz da çok küçük oldukları için emme durumları nasıl olur? Çıkabilir miyiz? Yapabilir miyiz? O düşünceler çok oldu, korkuttu bayağı beni... Hastane süreci sabırla beklemeyi öğretti. Süt sağmasını öğrendim. Bilmiyordum daha önce yapmamıştım. Çünkü önceki oğlum normal olmuştu. Prematür olmamıştı. O yüzden bi zorluk çekmemiştim. Bir problem olmamıştı. Bunda bayağı bir sıkıntı oldu diyebilirim yani. Çok üzüldüm özellikle göremediğim için. Emziremediğim için..."

6.anne: '...Çok üzüldüm... minicikti, çok ufaktı...'

9.anne: '... Bebeğimi yoğun bakıma gitti deyince, çok merak ettim. Kim merak etmez ki?'

\section{Hemşirelerden Beklentileri}

Annelerin hemşirelerden beklentileri; bebeklerinin intiyaçlarını karşılamaları, anne bebek etkileşimini sağlamaları, anneleri bebek bakımı için cesaretlendirmeleri, bebeğin durumu ile ilgili açık ve anlaşılır bilgi vermeleri olarak belirlenmiştir. Ayrıca anneler bebeklerine profesyonelce bakım verdikleri ve ihtiyaçlarını giderdikleri için YYBÜ hemşirelerine karşı minnettarlık hissettikleri belirlenmiştir.

1. anne: "... Allah razı olsun, çok memnun kaldım yani ilgililer çok çok ilgilendiler."

2. anne: "...Bu kadar uğraştıklarını bilmiyordum... Biz orda bebeklerimizi emziriyoruz diğer bebekleri de görüyoruz candan birebir kendi bebekleri gibi yani gerçekten. Bi kere soğukkanlılar öyle olmaları gerekiyor çünkü ben paniğim tutamıyorum bile... O kadar güzel ilgileniyorlar ki eviriyorlar, çeviriyorlar. Sabırlılar ve uğraşıyorlar bebeklerle. Bu kadar olduğunu bilmiyordum yani güzel..."

3. anne: "...Hani böyle bir şeyin olacağı aklımın ucundan dahi geçmiyordu. Ama buraya düşünce hepsinden Allah bin kere razı olsun. Yani herkes çok iyi ilgilendi. Bizlere karşı olsun... Bebeklerim iyi oldu. Ben buradan çok memnunum. Çok memnunum."

5. anne:"...En çok beklentim açık açık cevap vermeleri. Çünkü hani insan gerçekten görmediği için endişeleniyor. Tam ayrıntılı bilgi almadığı için çok tedirgin oluyor insan. Ben öyle oldum diğer anneleri bilmiyorum ama. Soruyorum sadece "iyi" hani benim için o iyi kelimesi yeterli olmadı. Çok ayrıntılı mesela diyorum kiloları olmadığı için veya eksik günler olduğu için şu kadar mama verdikten sonra emzirebileceksin diye bir açıklama olsaydı bana çok üzülmeyecektim. Inanın hatta ağlayacaktım bugün çağrılınca rahatladım. Büyük bi rahatık. Sadece açık ve net olarak söylenmesini isterim yani..."
7. anne: "...Yarasına dokunamıyorum aslında ama taburcu olacak deyince mecbur bugün yaptık biraz pansuman ama zor oldu valla... Ben cesaret edemediğimden hemşire hanım yapalım dedi. Yaptık biraz ama zor..."

10. anne: “...Prematüre bebek servisinde çalışan hemşireler nasıl bebeğim dediğimde sonuna kadar bilgi verdiler... Cesaretlendirdiler beni..."

\section{Bebeğin Bakımına İlişkin Görüşleri}

Anneler; bebeğin evde bakımına ilişkin korku ve tek başına yetemeyeceklerini hissettiklerini, bebeğin bakımında deneyimli bir kişiden destek almak gerektiğini ve hastanede bebeğin daha iyi bakıldığını düşündüklerini dile getirmişlerdir.

1. anne: “...Kendi başıma şimdi küçük olunca cesaret edemeyeceğim, bir büyükten yardım destek alacağım galiba."

2. anne: "...Yani elimizden geleni yapacağız da pek bilgim yok banyosu nasıl olur konuşmadık hiç beslenmesi, herhalde bu şekilde gider yani diye düşünüyorum... Korkuyorum, çok çok korkuyorum. Birebir bebekle tek başıma kalırsam ne yaparım diye düşünüyorum. Şimdi burada hemşireler var güveniyorum. ...Yapamayacağım dedim yani ne yapabilirim ki çok küçük. Düşürmekten korktum, emzirmekten, elimde tutmaktan bile korktum. ilk defa o kadar küçük bir bebek alıyorum çünkü ben kucağıma... Küçücük çok fazla yardıma muhtaç, bende öyleyim ama (gülerek) bende çok korkuyorum. Bakalım ne yapacağız yani zor bir süreç olacak..."

5. anne: "...Tek başına yetemem biliyorum. Yani ablamlar artık biraz destek olacaklar bana. Banyolarıyla ilgili zaten ilk önce oğlumu da ablamlar yıkamıştı... Ben biraz daha büyüdükten sonra. Şimdi bile eminim ablamlar yıkar. Çünkü çok küçük oldukları için. Çok fazla dikkat etmem gerekiyor..."

\section{TARTIŞMA}

Annelerin; erken dünyaya gelen bebeğinin ihtiyaçlarını karşılayamama endişesi, bebeğin bakımına ilişkin korkuları ve bebeğine bakım veren hemşirelerden beklentilerini belirlemek önemlidir ${ }^{16,19}$.

$\mathrm{Bu}$ çalışmada elde edilen bulgular annelerin; yaşadıkları duygular, bebeğin bakımına ilişkin görüşleri ve hemşirelerden beklentileri olmak üzere 3 ana tema üzerinden tartışılmıştır.

\section{Annenin Yaşadığı Duygular}

Prematüre doğum ve sonrasında bebeğin YYBÜ yatışı ebeveynler için kaygı ve stres verici bir durumdur. Ailenin keder yaşamasına ve psikolojik sorunlara neden olabiliri, ${ }^{1,2,6}$. Özellikle annelik rolünün kaybının en büyük stres kaynağı olduğu belirtilmektedir. Bu nedenle annelerin daha yoğun stres yaşadıkları ve bu kriz durumu ile baş edebilmeleri için desteğe ihtiyaç duydukları bilinmektedir ${ }^{14}$. Çalışmada da annelerin prematüre bebeğin sağlığına ilişkin büyük kaygı ve stres yaşadıkları, korku ve üzüntü hissettikleri saptanmıştır. Literatürde bebeği YYBÜ'ye yatan ebeveynlerin depresyon, anksiyete, uyku bozukluğu, yas ve izolasyon gibi psikolojik ve duygusal sorunlar yaşadıkları, bu durumu stres verici bir deneyim olarak tanımladıkları belirlenmiştir ${ }^{1,15,16,23-25}$. Bebeği YYBÜ'ye yatan ebeveynlerin deneyimlerine yönelik dokuz çalışmanın incelendiği bir sistematik derlemede 
hastaneye yatış stresi, ebeveynlik rollerinde değişim ve yenidoğanın hastaneye yatışının psikososyal sağlığa etkilerinin olduğu belirtilmiştir. Yine aynı derlemede bebeği YYBÜ'ye ebeveynlerin üzüntü, stres ve anksiyete yaşadığını, tüm ailenin özellikle annelerin süreçten daha çok etkilendiğini belirtilmiştir ${ }^{15}$. Benzer şekilde Whittingham ve ark. (2014) yaptıkları çalışmada ebeveynlerin stres nedenlerinin bebeğin YYBÜ’ye yatışıyla birlikte yaşadıkları kontrol kaybı ve bebekle etkileşim yetersizliği olduğunu belirtmişlerdir ${ }^{24,25}$. Yapılan diğer çalışmalarda da bebeğini emzirememe ve dokunamamanın kriz ve stres verici bir olmasının yanı sıra ${ }^{1,3,23}$ bebeği ile duygusal yakınlık kurmayada engel olduğu belirtilmiştir ${ }^{26}$. Ayrıca günlük yaşamın değişmesi, bebeğin durumuna ilişkin korkular, yetersiz bilgi, yoğun bakım ünitesinin çevresi ve ekiple yetersiz iletişimin de stresi arttıran faktörler olduğu gösterilmiştir ${ }^{1,3,23}$.

Bebeğin miadından önce doğması ailelerin; normal doğum sürecini yaşayamamasına, bebeğin ve annenin daha uzun süre hastanede kalmasına, bebekten ayrılmaya ve bebeği kaybetme korkusuna yol açabilir ${ }^{1}$. Aliabadi (2014)'de çalışmasında anneler için en büyük sorunun bebeklerinden ayrı kalmak olduğunu vurgulamıştır ${ }^{27}$. Psikolojik olarak erken doğuma hazır olmayan ailenin bebeğin doğumu ile şok ve anksiyete yaşadığı, özellikle annenin ciddi bir endişe ve korku içerisinde olduğu bilinmektedir ${ }^{1,26}$. Yaşanılan şokun sebebinin bebeğin görünümü ve yoğun bakıma yatırıması ileilgili olduğu bilinmektedir ${ }^{27,28}$. Hatta bebeğin taburculuğu sonrasında da annelerin önemli bir kısmında travmatizasyon belirtilerinin gözlendiği belirtilmektedir6,29. Çalışmamızda da anneler, ilk kez YYBÜ'ye girdiğinde ve bebeğini ziyaret ettiğinde, bebeğin büyüme ve gelişiminin nasıl etkileneceğine ilişkin endişe ve besleme-emzirmeye yönelikyoğun kaygıları olduğunu ifade etmişlerdir. Anneler bebeklerin bakımı ile ilgilenmek istediklerini ancak bebeğe zarar vermekten korktuklarını belirtmişlerdir. Benzer şekilde Çağlar ve ark. (2019) çalışmalarında komplike tedavi ve bakım uygulamaları dışında annelerin bebeklerinin yanında olmak istediklerini vurgulamışlardır ${ }^{30}$. Ayrıca literatürde annelerin, erken doğum yaparak sağlıksız bir bebek dünyaya getirdikleri için kendilerinin suçlu olduklarını düşündükleri belirtilmiştir ${ }^{16}$. Çalışmada da annelerin, annelik rolünü yerine getiremeyerek bebeğine yardım etmede kendini yetersiz hissettikleri tespit edilmiştir. Literatürde de bebekleri YYBÜ'lerde yatan annelerin en önemli problemlerinin bebeklerini kucaklayamamaları ve onları acı çekmekten koruyamadıklarını için kendilerini kötü hissetmeleri $^{6}$ ve bebeklerinden uzun süre ayrı kalmaları ${ }^{31}$ olduğuna vurgu yapmıştır. Yine Shin (2004) çalışmasında annelerin bebek bakımında yetersiz kalacaklarını düşündüklerinde utanma, suçluluk ve başarısızlık duyguları yaşadıklarını belirlemiştir ${ }^{32}$. Bu bağlamda Beverly (2016) çalışmasında YYBÜ'ye bebeği yatan annelerin zihinsel sağlıklarının öneminden bahsederek annenin zihinsel sağlığını sürdürebilmek noktasında kaynakların doğru kullanılmasının gerekliliğine vurgu yapmıştır ${ }^{33}$.

\section{Hemşirelerden Beklentileri}

Hemşireler, yoğun bakım sürecinde ailelerin yaşadığı sorunları tanımlayarak, terapötik iletişim kurma, duygusal destek sağlama, hızlı ve doğru bilgilerle ebeveynleri destekleme, bebeğin bakımına katılımını sağlama gibi girişimlerle stres yaşayan ailenin sorunlarla baş edebilmesine yardımcı olurlar $9,12,16,34$. Aile merkezli ve destekleyici hemşirelik girişimleri ailelerin yaşadığı olumsuz duyguları azaltarak olumlu psikososyal sonuçlar almayı sağlar ${ }^{16}$. Preterm bebeğin doğumu stres, postpartum depresyon, post travmatik stres bozukluğu, bağlanma ve süt üretimi açısından bir risk faktörü olarak sayılmaktadır ${ }^{10,35}$. Annenin bebeği ile ilişki kurabilmesi için YYBÜ sağıık ekibi üyeleriyle güvenilir bir iletişim başlatması gerekir ${ }^{3,36}$. Heo ve Oh (2019) çalışmalarında preterm bebek ebeveynlerinin ekiple etkili iletişime ihtiyaç duyduklarını belirtmiştir ${ }^{35}$. Bu süreçte hemşirenin en önemli rollerinden biride bebeğin bakımında ebeveynlere rehberlik etmek ve ebeveynlik rollerini desteklemektir ${ }^{19,34,35}$. Bebeği YYBÜ'ye yatan annelerin intiyaçlarına yönelik yapılan bir sistematik derlemede; annelerin gereksinimleri bilgilendirici eğitim, bebeğini koruyabilme ve bakımına katılım isteği, bireyselleştirilmiş bakım ve YYBÜ sağlık ekibi üyeleriyle etkili olumlu posttravmatik iletişim kurabilme olarak belirtmişlerdir ${ }^{31}$. Yine Çakmak'ın (2015) çalışmasında YYBÜ'lerde anneler yenidoğanların bakımına katılırken $\% 91,8^{\prime}$ inin hemşirelerden yardım aldıkları bildirilmiştir ${ }^{36}$. Bu çalışmada da annelerin hemşirelerden beklentileri; bebeklerinin ihtiyaçlarını karşılamaları, anne bebek etkileşimini sağlamaları, anneleri bebek bakımı için cesaretlendirmeleri, bebeğin durumu ile ilgili açık-anlaşıı bilgi vermeleri olarak belirlenmiştir. Yapılan çalışmalarda da annelerin ebeveynlik rollerindeki değişime vurgu yaptıkları ve en çok doğru-anlaşılır bilgiye gereksinim duydukları görülmüştür, ${ }^{16,37}$. Bu durum bebek annelerinin ebeveynlik rollerini yerine getirememeye bağı kendilerini yetersiz hissetmeleri ve işlevini bilmedikleri birçok teknolojik araç içinde bebeklerini yalnız bırakmak zorunda kalmaları ile ilişkilendirilebilir. Avaz ve ark. (2018) çalışmalarında YYBÜ annelerinin en büyük sorunlarının bebeklerini yalnız bırakmak olduğuna vurgu yapılmıştır ${ }^{31}$.

Çalışmaya katılananneler, YYBÜ'nün streslerini arttırdığını ancak sağlık ve bakım hizmetlerinden memnun olduklarını ifade etmişlerdir. Bebeği YYBÜ'nde yatan annelerin deneyimlerine yönelik yapılan başka çalışmalarda yoğun bakımın stresi arttırdığı ancak YYBÜ'de samimi bir karşılama ve sakinlik olduğunu, sağlık hizmetlerinden memnun olduklarını, ekip ve diğer ebeveynlerle iletişim sayesinde kendilerini daha rahat hissettiklerini bildirmişlerdir ${ }^{3,12,15,18,34}$. Bu sonuçlar YYBÜ çevresinin ve ekibinin, ebeveynlerin duygularını ve düşüncelerini etkilediğini göstermektedir.

Bebeği YYBÜ'ye yatan annelerin, tıbbi veya sosyal açıdan yaşadıkları her türlü sıkıntılı durumla mücadelede en büyük desteği sağlık ekibinden aldıkları bildirilmiştir ${ }^{1,6}$. Yapılan bir çalışmada; anne ve hemşire arasında kurulan sosyal ilişki ve sohbetin, annelerin kendilerini ifade etmelerinde, deneyimlerini ve duygularını paylaşmada ve bebeklerinin bakımında özgüvenlerini kazanmalarında etkili olduğu bulunmuştur ${ }^{37}$. Annelerle gerçekleştirecek sosyal etkileşim ve iletişimin, sorunların çözümünde çok daha başarılı olacağı unutulmamalıdır. Wigert ve ark. (2006)'da hemşire-anne 
etkileşiminin kurulabilmesi için iletişimde sürekliliğin sağlanması gereğine vurgu yapmışlardır ${ }^{38}$. Hemşirelerin, ebeveynlerin bireysel özelliklerini, stres ve ebeveynlik rolüne katılma düzeylerini, bebeğin sağlık durumunu değerlendirebilme ve kendilerini yeterli hissetmelerini sağlamak amacıyla, yenidoğanın bakımına aktif bir şekilde katılmalarını desteklemeleri önemlidir ${ }^{1,7}$.

\section{Bebeğin Bakımına İlişkin Görüşleri}

Yenidoğan yoğun bakım ünitelerinde yatan preterm yenidoğanların sağkalım oranları uygulanan bakıma dayalıdır. Aileler YYBÜ'lerde sağlık profesyonelleri tarafından verilen bakımı yenidoğanlar taburcu edildiğinde evde devam ettiremeyecekleri konusunda yoğun endişe yaşarlar. Özellikle annenin kaygıları bebeğin taburculuğu yaklaştıkça artmaktadır. Anne bebeğe zarar vermekten korktuğu için ona dokunmaktan bile kaçınabilir hatta bebeğin bakımına katılmak zor ve kaygı verici olabilir6,18,27. Ancak literatürde annelerin bu dönemde bebeklerine dokunmak ve yakın temas kurmak arzusunda olduğu yönünde de kanıt mevcuttur ${ }^{39}$.

Ebeveynlerin yaşadığı stresin nedeni bakım konusunda yardım alamama, bakıma dahil edilmeme, uzak tutulma, bebekle etkileşim ve ebeveynlik konusunda yeterli bilgi verilmemesi olarak belirtilmektedir ${ }^{14,40}$. Çalışmada, annelerin bebeğin evde bakımını yapamayacağına ilişkin korkusu olduğu, tek başına yetemeyecekleri, bebeğin bakımında deneyimli bir kişiden destek alacağı ve hastanede bebeğin daha iyi bakıldığı şeklinde ifadelerde bulundukları belirlenmiştir. Harish ve arkadaşları (2018) ülkelerinde rutinde uygulanandan farklı bir uygulama modeli kullandıkları çalışmada anne ve yenidoğanın birlikte kalabildikleri hastane koşullarını sağlayarak annelerin uyumunu takip etmişlerdir ${ }^{41}$. Annelerin bakım ve tedaviye katılım konusunda daha kolay eğitilebildiğini göstermişlerdir.

Swift ve Scholten (2010) 9 ebeveynle yaptığı nitel çalışmada ebeveynlik rolünde değişimler yaşandığını, ebeveynlerin bebeklerini tutma yeteneklerinin azaldığını ve çoğu bebekte beslenme sorunlarının olduğunu tespit etmiştir ${ }^{42}$. Whittinghamve ark. (2014) çalışmalarında ebeveynler hastaneden taburcu olduktan sonra bebeğin gelişim konusunda daha obsesif (takıntılı) olduklarını, tıbbi durumu ve gelişimine ilişkin belirti ve bulguları çok sık takip ettiklerini belirtmişlerdir ${ }^{24}$. Heinemann ve ark.(2013) da 15 ebeveynle yaptığı nitel çalışmalarında kanguru bakımı ve bebeğin bakımına aktif katılımın ebeveynlerin kontrol duygusunu arttırdığını, onların bebekleriyle olmaya ilişkin motivasyonlarını güçlendirdiğini belirtmişlerdir ${ }^{3}$.

Prematürelerin evde bakım gereksinimlerinin belirlenerek ebeveynlerin bebeğin evde bakımı ile bilgi ve becerilerinin geliştirilmesi çok önemlidir ${ }^{1,2,27}$. Yapılan çalışmalarda preterm bebeği olan anne ve babaların evdeki ebeveynlik yeterlilikleri konusunda kendilerine daha az güvendikleri, annelerin büyük birkısmının bebek bakımında yardımcı kişi desteğine intiyaç duyduğu ve bebeğin evdeki bakımına yönelik eğitim gereksinimlerinin olduğu belirtilmektedir ${ }^{2,41}$ 44. Hemşireler YYBÜ’den taburcu olacak bir yenidoğanın ev ortamının hazırlanmasında önemli rolü vardır. Aile merkezli bakım doğrultusunda taburculuk öncesi prematüre bebeğin ev ortamı değerlendirilerek, ebeveynlere prematüre bebeğin evde bakımı ile ilgili eğitimler verilmesi önemlidiri,2,44. Annelerin YYBÜ'den taburcu olduktan sonraki deneyimlerini belirlemeye yönelik yapılan bir çalışmada karışık ve net olmayan bilgi kaynakları, taburculuk durumu, etkin annelik, devam eden kabus temaları şeklinde sorunlar belirlenmiş ve hemşirelerin bebeğin YYBÜ'den taburculuğunda anneleri desteklemesi önerilmiştir ${ }^{43}$.

\section{SONUÇ ve ÖNERILER}

Çalışma sonuçları ışığında YYBÜ'lerde bebeği yatan annelerin bebek bakımı ile ilgili yoğun kaygılar yaşadıkları ve bu durumla başa çıkmakta zorlandıkları söylenebilir. Annelerin baş etmelerini güçlendirmede bireyselleştirilmiş gelişimsel bakım uygulamaları çerçevesinde annelerin bakıma mümkün olduğunca aktif katılması ve hem anne hem de yenidoğan sağlığına katkı sağlayacağı için hemşirelerin anneler ile terapötik etkileşim içinde olmaları önerilebilir. Ayrıca, farklı hastane yoğun bakım ünitelerinde daha fazla örneklem ile karşılaştırmalı olarak planlanacak çalışmaların literatüre katkı sağlayacağı düşünülmektedir.

Etik Kurul Onayı: Bilecik Şeyh Edebali Üniversitesi Etik Kurulu'ndan, 09/03/2015- 54674167-604.01.02/ tarih ve sayı numarası ile etik kurul onayı alınmıştır.

Çıkar Çatışması: Yoktur.

Finansal Destek: Bildirilmemiştir.

Katılımcı Onamı: Çalışmaya katılan prematüre bebek annelerinden yazılı onam alınmıştır.

Yazar katkıları:

Araştırma dizaynı: DE, MB, ZK, ÖM, IY.

Veri toplama: DE, ÖM, ÖB

Literatür araştırması: DE, ÖB, ZK, MB, iY.

Makale yazımı: DE, ÖB, ZK, IY, ÖM, MB

Teşekkür: Çalışmaya değerli görüşleri ile destek veren prematüre bebek annelerine teşekkür ederiz.

*Çalışma 05-07 Mart 2015 tarihinde gerçekleştirilen Erciyes Pediatri Hemşireliği Kongresinde sözel bildiri olarak sunulmuştur.

Ethics Committee Approval: Approval was obtained from Bilecik Şeyh Edebali University Ethics Committee (Date: 09/03/2015, Decision Number: 54674167-604.01.02).

Confict of Interest: Not reported.

Funding: None.

Exhibitor Consent: Written consent was obtained from mothers of premature babies who participated in the study. Author contributions:

Studydesign: DE, MB, ZK, OM, iY

Datacollection: $\mathrm{DE}, \mathrm{OM}, \mathrm{OB}$

Literaturesearch: $D E, O B, Z K, M B$, IY

Draftingmanuscript: $\mathrm{DE}, \mathrm{OB}, \mathrm{ZK}$, IY, OM, MB

Acknowledgement: We would like to thanks the mothers of premature babies who supported the study with their valuable opinions.

*The study was presented as an oral presentation at the Erciyes Pediatric Nursing Congressheld on 05-07 March 2015

\section{KAYNAKLAR}

1. Akbaş $M$, Akça $E$, Şenoğlu $A$, Sürücü ŞG. Yenidoğan yoğun bakım ünitesinde bebeği yatan anne-babaların 
anksiyete ve depresyon düzeylerinin incelenmesi. STED. 2019;28(2):87-97.

2. Taş Arslan F, Turgut R. Prematüre bebek annelerinin evdeki bakım gereksinimleri ve bakım verme yeterliliklerini algılama durumları. DEUHYO ED. 2013;6(3):119-24.

3. Heinemann AB, Hellström-Westas L, Hedberg Nyqvist K. Factors affecting parents' presence with their extremely preterm infants in a neonatal intensive care room. Acta Paediatrica. 2013;102(7):695-702.

4. Küçükoğlu S, Çelebioğlu A, Coşkun D. Yenidoğan kliniğinde bebeği yatan annelerin postpartum depresyon belirtileri ve emzirme özyeterlilik düzeylerinin belirlenmesi. Gümüşhane Üniversitesi Sağlık Bilim Dergisi. 2014;3(3):921-32.

5. Busse M, Stromgren K, Thorngate L, Thomas KA. Parents' responses to stress in the neonatal intensive care unit. Crit Care Nurse. 2013;33(4):52-9.

6. Toivonen $M$, Lehtonen L, Löyttyniemi $E$, Axelin $A$. Effects of single family rooms on nurse parent and nurse infant interaction in neonatal intensive care unit. Early Hum Dev. 2017;106-107:59-62.

7. Çelen R, Taş Arslan F. The anxiety levels of the parents of premature infants and related factors. J Pediatr Res. 2017;4(2):68-74.

8. Sloan K, Rowe J, Jones L. Stress and coping in fathers following the birth of a preterm infant. Journal of Neonatal Nursing. 2008;14(4):108-15.

9. Cockcroft $\mathrm{S}$. How can family centred care be improved to meet the needs of parents with a premature baby in neonatal intensive care? Journal of Neonatal Nursing. 2012;18(3):105-10.

10. Jakimowicz S, Perry LA. Concept analysis of patientcentred nursing in the intensive care unit. JAN. 2015;71(7):1499-517.

11. Miles MS, Holditch-Davis D, Schwartz TA, Scher M. A longitudinal study of depressive symptoms in mothers of prematurely born infants. J Dev Behav Pediatr. 2007;28(1):36-44.

12. Russell G, Sawyer A, Rabe H, Bliss JA, Gyte G, Duley L, et al. Parents' views on care of their very premature babies in neonatal intensive care units: Aqualitative study. BMC Pediatr. 2014;14(230):1-10.

13. Güneş $N$, Çavuşoğlu $H$. Effects of a homefollow-up program in Turkey for urban mothers of premature babies. PHN. 2020;37(1):56-64.

14. Chertok IRA, McCrone S, Parker D, Leslie N. Review of interventions to reduce stres among mothers of infants in the NICU. Advances in Neonatal Care. 2014;14(1):307.

15. Maghaireh DF, Abdullah $\mathrm{KL}$, Chan $\mathrm{CM}$, Piaw $\mathrm{CY}$, Kawafha MMA. Systematic review of qualitative studies exploring parental experiences in the neonatal intensive care unit. J Clin Nurs. 2016;25(19):2745-56.

16. Obeidat HM, Bond EA, Callister LC. The parental experience of having an infant in the newborn intensive care unit. J Perinat Educ. 2009;18(3):23-9.

17. Korkmaz Z, Derince D, Başdaş Ö, Bayat M, Erdem E. Yenidoğan yoğun bakım ünitesinde bakımın sürekliliğ uygulamasına ilişkin hemşirelerin görüşleri: Nitel bir çalışma. Ordu Üniversitesi Hemşirelik Çalışmaları Dergisi. 2020;3(3):211-17.

18. Arnold L, Sawyer A, Rabe H, Abbott J, Gyte G, DuleyL, et al. Parents' first moments with their very preterm babies: a qualitative study. BMJ Open. 2013,3(4):1-7.

19. Subhashini L, Radha MS, Baby GK. Mothers perception of health care needs of preterm neonates in intensive care unit. J Clin Biomed Sci. 2016;6(2):59-62.

20. Parahoo K. Nursing research principles, process and issues. 2nd ed. New York: Palgrave Macmillan Ltd; 2006. Chapter 4, Qualitative Research; p.90-144.

21. Christensen LB, Johnson RB, Turner LA. Research methods, design and analysis. Boston: Pearson Education Inc; 2011. Chapter 3, Foundations of Research; p.131-158.

22. Kümbetoğlu B. Sosyolojide ve antropolojide niteliksel yöntem ve araştırma. 2. Basım. İstanbul: Önsöz Basım Yayıncılık; 2008. Bölüm 4, Niteliksel araştırmalarda veri oluşturma teknikleri, s.71-117.

23. Watson G. Parental liminality: Away of understanding the early experiences of parents who have a very preterm infant. J ClinNurs. 2011;20(9-10):1462-71.

24. Whittingham K, Boyd RN, Sanders MR, Colditz P. Parenting and prematurity: understanding parent experience and preferences for support. JCFS. 2014;23:1050-61.

25. Yayan EH, Özdemir M, Düken ME, Dağ YS. Yenidoğan yoğun bakım ünitesinde bebeği yatan ebeveynlerin stres düzeylerinin belirlenmesi, GÜSBD. 2019;8(1):829.

26. Gürol A, Tekgündüz AŞ, Apay SE, Özdemir S, Güven R. Yenidoğan yoğun bakım ünitesinde duygusal yakınlık: Kalitatif bir çalışma. Journal of Psychiatric Nursing. 2020;11(4):261-67.

27. Aliabadi F, Kamali M, Borimnejad L, Rassaani M, Rasti $M$, Shafaroodi $N$, et al. Supporting emotional needs of Iranian parents with premature infants admitted to neonatal intensive care units. Med J Islam Repub Iran. 2014;12:28-53.

28. Musabirema P, Brysiewicz P, Chipps J. Parents perceptions of stress in a neonatal intensive care unit in Rwanda. Curationis. 2015;38(2):1-8.

29. Howe TH, Sheu CF, Wang TN, Hsu YW. Parenting stress in families with very low birth weight preterm infants in early infancy. Res Dev Disabil. 2014;35(7): 1748-56.

30. Çağlar S, Ar I, Yaşa B, Kurt Ş. Yenidoğan yoğun bakım ünitesinde aile merkezli bakım: Anne görüşleri. STED. 2019;28(2):120-6.

31. Ayvaz $E$, Açıkgöz A. Nitel bir çalışma: Yenidoğan yoğun bakım ünitesinde tedavi gören bebeklerin ailelerinin görüş ve beklentilerinin belirlenmesi. Osmangazi Tıp Dergisi. 2018;41(3):271-78.

32. Shin HS. Maternal identity in mothers of premature infants admitted in NICU. J Korean Acad Child Health Nurs. 2010;10(1):117-25.

33. Beverly R,Greene MM, Kratovil AL, Meier PP. Resilience in mothers of very-low-birth-weight infants hospitalized in the NICU. JOGNN. 2017;46(3):434-44. 
34. Abuidhail J, Al-Motlaq M, Mrayan L, Salameh T. The lived experience of Jordanian parents in a neonatal intensive care unit: A phenomenological study. J Nurs Res. 2017;25(2):156-62.

35. Heo YJ, Oh WO. The effectiveness of a parent participation improvement program for parents on partnership, attachment infant growth in a neonatal intensive care unit: A randomized controlled trial. Int J Nurs Stud. 2019;95:19-27.

36. Çakmak E. Yenidoğan yoğun bakım ünitesinde bebeği yatan annelerin bakıma katılmalarının kaygı düzeyleri ve bakım sorunlarını çözme becerileri ile ilişkisi (Yüksek lisans tezi). Aydın: Adnan Menderes Üniversitesi; 2015.

37. Fenwick J, Barclay L, Schmied V. Craving closeness: A grounded theory analysis of women's experiences of mothering in the special care nursery. Women and Birth. 2008;21(2):71-85

38. Wigert $H$, Johansson $R$, Berg $M$, Hellstrom A. Mothers' experiences of having their newborn child in a neonatal intensive care unit. Scand J Caring Sci. 2006;20(1):3541.

39. Feeley N, Genest C, Niela-Vilén H, Charbonneau L, Axelin A. Parents and nurses balancing parent-infant closeness and separation: A qualitative study of NICU nurses' perceptions. BMC Pediatr. 2016;16(1):1-13.

40. Sturdivant L, Warren NA. Perceived met and unmet needs of family members of patients in the pediatric intensive care unit. Crit Care Nurs Q. 2009;32(2):14958.

41. Harish C, Pratima M, Sugandha A. Mother-neonatal intensive care unit (M-NICU): A novel concept in newborn care. Indian Pediatrics. 2018;55:1035-36.

42. Swift MC, Scholten I. Not feeding, not coming home: parental experiences of infant feding difficulties and family relation ships in a neonatal unit. J Clin Nurs. 2010;19(1-2):249-58.

43. Zamanzadeh V, Namnabati M, Valizadeh L, Badiee Z. Mothers' experiences of infants discharge in Iranian NICU culture. A qualitative study. Adv Neonatal Care. 2013;13(4):1-7.

44. Özbey H, Sezer Efe Y, Erdem E. Preterm bebeği olan aile ve hemşirelik yaklaşımı. HUHEMFAD. 2020;7(3):29298. 